\title{
NOTES
}

\section{PEREGRINE FALCON DELIVERS FISH TO FLEDGLING IN NORTHERN NEW MEXICO}

DALE W. STAHLECKER, Eagle Environmental, Inc., 30 Fonda Road, Santa Fe, New Mexico 87508; dale@eagleenvironmental.net

E. LARSON PANZY and KYLE J. TATOR, Jicarilla Game and Fish Department, P. O. Box 313, Dulce, New Mexico 87528

The Peregrine Falcon (Falco peregrinus) is well known as a predator of aerial prey. White et al. (2002) estimated that the diversity of birds it captures exceeds 2000 species worldwide. Its primary mammalian prey are also aerialists: bats. In North America, recorded prey encompass at least 429 species of birds and 23 of mammals, including 10 of bats (White et al. 2002). Fish would not appear to be available as food for aerial hunting Peregrines. Nevertheless, Cade (1960) reported an incident of capture of live fish: his visit to an Alaska eyrie had agitated the adults, which circled above him, calling. The male then stooped and captured an arctic grayling (Thymallus arcticus) from a school leaping from the nearby river and transferred it to his mate, who departed the immediate area, apparently because of the human presence. In California, Peregrines have been seen pirating fish from Ospreys (Pandion haliaetus) (B. Walton in White et al. 2002). Our Figure 1 represents what we believe is the first photo-documentation of a Peregrine Falcon feeding on a fish.

Since 2002, Peregrine Falcon breeding has been monitored annually in the Jicarilla Apache Nation, a 3500- $\mathrm{km}^{2}$ sovereign entity in north-central New Mexico. On 23 July 2017, as Panzy approached one of the eyries being monitored, he noted a juvenile having difficulty maintaining its perch in a tree, indicative of its recent fledging. An adult falcon flew in, landing on the cliff-top with a beheaded, but fresh, $\sim 40-\mathrm{cm}$ rainbow trout (Oncorhynchus mykiss). The fledgling flew to the adult, took the prey, and consumed most of it within 15 minutes.

The eyrie cliff is centrally located among a number of lakes stocked with rainbow trout. One small lake, $6 \mathrm{~km}$ distant, had experienced a partial fish kill the previous week, and it is possible the trout was picked up as carrion there, but it would have appeared dry, not shiny (see Figure 1). Furthermore, there is only one published case of a Peregrine eating carrion, a carcass of a white-tailed deer (Odocoileus virginianus) (Holland 1989).

Larger lakes are Heron and El Vado reservoirs, 8-20 km away and home to >15 nesting pairs of Ospreys (Stahlecker 2010) and three pairs of Bald Eagles (Haliaeetus leucocephalus) (Stahlecker and Walker 2010; Tator unpubl. data). Worldwide, published reports of kleptoparasitism by Peregrine Falcons include their targeting at least 16 other species of diurnal raptors, corvids, gulls, and the Short-eared Owl (Asio flammeus) (Rigolosi and Hayes 2018, Swem and Matz 2018). Given that Peregrines have been seen pirating from Ospreys (B. Walton in White et al. 2002), we think it is much more likely that the adult Peregrine pirated the trout from an Osprey or possibly from a Bald Eagle.

Monitoring of breeding of the Peregrine Falcon and Golden Eagle (Aquila chrysaetos) has been supported by contracts between the Jicarilla Game and Fish Department and Eagle Environmental, Inc. Tom Watts, retired tribal biologist, saw the need and initiated the effort. Megan Ruehmann's review improved the draft manuscript, while those of Ted Swem and Daniel D. Gibson further focused the final publication.

\section{LITERATURE CITED}

Cade, T. J. 1960. Ecology of the Peregrine and Gyrfalcon populations in Alaska. Univ. Calif. Publ. Zool. 63:151-290. 


\section{NOTES}

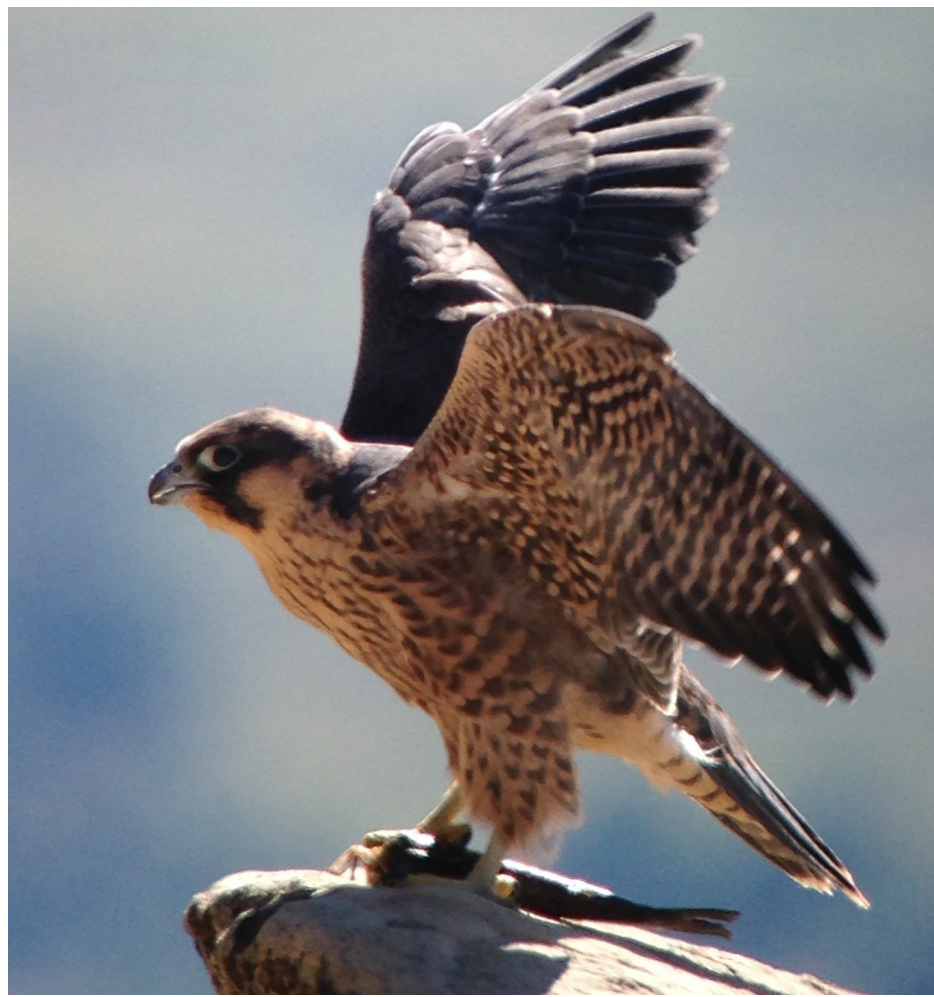

Figure 1. Fledgling Peregrine Falcon with rainbow trout delivered by adult female, Jicarilla Nation, New Mexico, 23 July 2017.

Photo by E. Larson Panzy

Holland, D. C. 1989. An instance of carrion-feeding by Peregrine Falcon (Falco peregrinus). J. Raptor Res. 23:184.

Rigolosi, F., and Hayes, F. E. 2018. Attempted kleptoparasitism of a White-tailed Kite by a Peregrine Falcon. W. Birds 49:142-144; doi 10.21199/WB49.2.5.

Stahlecker, D. W. 2010. Osprey, in The Raptors of New Mexico (J.-L. Cartron, ed.), pp. 87-105. Univ. New Mexico Press, Albuquerque.

Stahlecker, D. W., and Walker, H. A. 2010. Bald Eagle, in The Raptors of New Mexico (J.-L. Cartron, ed.), pp. 131-149. Univ. New Mexico Press, Albuquerque.

Swem, T., and Matz, A. C. 2018. Natural history and recovery of Arctic Peregrine Falcons along the Colville River, Alaska, 1981-2011, in Trends and traditions: Avifaunal change in western North America (W. D. Shuford, R. E. Gill, Jr., and C. M. Handel, eds.), pp. 132-147. Studies of Western Birds 3. W. Field Ornithol., Camarillo, CA; doi 10.21199/SWB3.6.

White, C. M., Clum, N. J., Cade, T. J., and Hunt, W. G. 2002. Peregrine Falcon (Falco peregrinus), in The Birds of North America (A. F. Poole and F. B. Gill, eds.), no. 660. Birds N. Am., Inc., Philadelphia; doi.org/10/2173/bna.660. 